\title{
Reviving the Urban Water-Edge: History and Heritage Morphology in the Envisaging of Chittagong City
}

\author{
Md Mustiafiz Al Mamun \\ (iD) https://orcid.org/0000-0001-8226-252X \\ Chittagong University of Engineering and Technology, Bangladesh \\ Pranjib Paul \\ Chittagong University of Engineering and Technology, Bangladesh \\ Sadman Noor \\ Chittagong University of Engineering and Technology, Bangladesh
}

Anjuman Ara Begum

Doshomik Sthapathi, Bangladesh

\begin{abstract}
Ancient settlements were dependent on the availability of water for sustainable living, ritual values, and economic purposes. Today, many Tropical Asian cities provide examples of urban settlements within water landscapes, yet these cities struggle with water issues, and face challenges in creating a contextual morphological identity. This paper explores urban waterfront heritage through a case study of Chittagong, Bangladesh. The city is experiencing rapid unplanned urbanisation, insensitive land use and the demolition of historical buildings along waterways, which in turn has created a contextual crisis in the built environment and social living. To explore the relationship of built heritage with the wateredge, this paper examines historical architectural styles using urban morphological codes. Results show that the historical orientations, accessibility, and functions of heritage buildings are explicitly and sensitively connected with the water-edge. The paper argues that physical and spatial components of urban structure and water landscape, incorporating the lessons of urban history, could become a tool to preserve urban heritage. However, to enhance the image of the city in a sustainable manner along water-edges, it is crucial to use the potentiality of water landscape with the heritage-based morphologies in current urban design and development practices.
\end{abstract}

Keywords: Chittagong City, Colonial Period Architecture, Historical Essence, Tropical Urban Heritage, Urban Morphological Coding, Urban Water-Edge Design

eTropic: electronic journal of studies in the tropics publishes new research from arts, humanities, social sciences and allied fields on the variety and interrelatedness of nature, culture, and society in the tropics. Published by James Cook University, a leading research institution on critical issues facing the worlds' Tropics. Free open access, Scopus Listed, Scimago Q2. Indexed in: Google Scholar, DOAJ, Crossref, Ulrich's, SHERPA/RoMEO, Pandora. ISSN 1448-2940. Creative Commons CC BY 4.0 free to download, save and reproduce. To cite, include: Author(s), Title, eTropic, volume, issue, year, pages and DOI: http://dx.doi.org/10.25120/etropic.19.2.2020.3775 
eTropic 19.2 (2020) Special Issue: Sustainable Tropical Urbanism

\section{Introduction and Background}

$\mathrm{E}$

arly civilisations were mostly settled near waterways and depended on the availability of water for sustainable living, ritual values, and economic advantages provided by transport and connectivity (Abshirini \& Koch, 2016; Gu, 2013; Salim \& Mohamed, 2018; Silva et al., 2006; Smith \& Ferrari, 2012). Due to rapid urbanisation and new modes of economic growth, many historical water-edge port industries are no longer in existence, rendering these areas derelict (Rahman \& Imon, 2017). In Asia, many ancient cities embodied the example of urban settlements along waterways (Yang \& Soraya, 2013). However, due to increases in population, economic expansion, and the advancement of modern urban infrastructure, many cities moved their central business districts from waterfront locations inland (Salim \& Mohamed, 2018). The tremendous pressures of urbanisation have also degraded waterfronts and their waterways, resulting in reduced water drainage capacity, increased water pollution, unpredicted waterlogging, and flash floods (Rashid et al., 2018). These phenomena have consequently raised significant contextual challenges in identifying urban morphological patterns, which affect urban heritage conservation and/or preservation planning (Hussain et al., 2015; Samsudin \& Jaffar, 2017; Xie \& $\mathrm{Gu}, 2015)$. A key issue remains how far urban design and development strategies can spread inland and expand along waterways without affecting heritage structures which, importantly, reflect the cultural and historic identity of a city. The UNESCO World Heritage Centre has stated that heritage conservation/preservation is of significance to every society in the contemporary era (Samsudin \& Jaffar, 2017). Evidence of past heritage can provide a wider sense of social belonging and identity which is not isolated to a building but incorporates the site's social, cultural, economic and environmental surroundings - which, in turn, create a series of opportunities and challenges in relation to the physical setting (Ocón, 2018; Salim \& Mohamed, 2018; Samsudin \& Jaffar, 2017). Hussain et al. (2015) state that these physical qualities provide a useful tool for historic appraisal and add a visual sense of heritage and belonging in urban settings. For instance, in tropical Southeast Asia, the Melaka and Georgetown Waterfront Heritage areas in Malaysia have been recognised as World Heritage Sites (WHS) because of their ancient historic value, and explicit architectural features from the colonial period (Salim \& Mohamed, 2018). On the other side of the colonial world, in the northern temperate region of England, the port city of Liverpool was registered as a World Heritage Site in 2004 in recognition of several prominent landmark buildings along the Pier Head and Albert Dock waterfront (Liverpool City Council, 2020).

Despite the rising significance of heritage, the complex qualities of historic water-edge built environments have, until recently, been overlooked in contemporary urban design (Liu \& Jensen, 2018; Al Mamun et al., 2019; Schuch et al., 2017). However, over the 
eTropic 19.2 (2020) Special Issue: Sustainable Tropical Urbanism

last decade there have emerged several established approaches and design frameworks to deal with contemporary urban challenges that impact urban waterfronts and heritage. In the critical review of these frameworks, Water Sensitive Urban Design (WSUD), currently the most significant and predominant concept, has addressed aspects of technological installation rather than built-form and nature-based practices (Wong, 2006) leaving a contextual crisis regarding the urban built environment and social living $(\mathrm{Gu}, 2014)$. A further contextual challenge involves the dynamic life of cities, which are always changing through transforming old structures to new forms (Samsudin \& Jaffar, 2017), and, for heritage cities, create a dilemma for experts in how to maintain current morphology and still preserve their heritage status (Samsudin \& Jaffar, 2017; Shamsuddin et al., 2012). The challenge in heritage preservation can be described as one of expressing a sense of place, which involves sensitivity to history, culture, built and natural environments (Ocón, 2018; Samsudin \& Jaffar, 2017).

Traditionally, architectural practices have mainly involved designing buildings through different typologies, building styles and materials using different technologies; yet theoretically they are expected to inform the effective management of new development and redevelopment, appraising the character of the locality and wider urban context (Al Mamun \& Kim, 2020; Gu, 2014). Gu (2010) notes the importance of an integration framework of economic development, environmental management, and urban design needs, which requires a wider connection with the historical development of the urban built environment of the city. However, decision-making conflicts between local authorities and local residents are evident due to new commercial developments replacing historical sites and affecting the quality of local life and surroundings (Rahman \& Imon, 2017). This dilemma indicates that there is a need to investigate how cities can achieve a balanced integration of heritage and contemporary built environments for reviving waterfronts. This will require a contextual approach. Contemporary practices of architecture ignore contextual design (Daglioglu, 2015). Likewise, in contemporary theoretical and discursive studies of architecture, contextual reflection on senses of place, despite its once central role in architectural philosophy, retains only scant analysis and is generating insufficient interest among academics and practitioners (Daglioglu, 2015; Gültekin, 2012).

Informed by a contextual approach, this research paper undertakes a case study of the city of Chittagong. It focuses on various forms of natural and human designed urban landscape settings which comprise the current central business district and the historic trading territory as documented by the Chittagong Metropolitan Area (CMA) urban development plan. The specific objectives of this research are: (1) to unpack the present conditions of the city and explore urban waterfront heritage in relation to its users, and (2) to examine the role of architectural patterns in historical built forms influenced by waterfront settings. A mixed-method approach is used to illustrate the 
eTropic 19.2 (2020) Special Issue: Sustainable Tropical Urbanism

issues and objectives. The evidence was collected from a variety of sources, including as secondary documents, experts' opinions, and the local knowledge of users around the waterfront area. The research concludes that there is an urgent need for crafting and designing a more sustainable urban morphology for reviving urban waterfront space in the envisaging of the Chittagong city.

\section{Urban Development History of Chittagong along Waterways}

Chittagong is a southern waterfront city on the Bay of Bengal. It lies below the Tropic of Cancer and has a hot monsoon climate. The city also has a unique water landscape and environment of sea and river deltas and is susceptible to tropical cyclones and flooding. The tropical regions of the world are undergoing rapid population growth and changes in economic development and urbanisation at the same time as experiencing climate change effects (Harding et al., 2016). In the case of Chittagong, rapid urban change has particular impacts on the city's waterways and water-edge design which is of vital significance to the city historically, culturally and environmentally. Chittagong is an ancient port city located on the banks of the Karnaphuli River with its long history including numerous sub-continent eras as well as the British colonial period. During the colonial period it was known as the gateway to Bengal. Historic buildings of heritage value convey this period and the evolution of Chittagong from a town to a city.

Chittagong Town (as an urban centre) began in the late $17^{\text {th }}$ century during the British colonial era. In the early history of the British period, Chittagong Town was recognised as a business hub characterised by dense settlements connected with the trading of goods along the region's waterways. Since water was the prime transport system, the waterfront was the recognised business and trading centre (Figures $1 \& 2$ ). Thus, urban development continued to expand along water channels. However, in Chittagong Town only a few brick-built houses were to be found in the later $17^{\text {th }}$ century. As recorded by Buchanan Hamilton these were inhabited by the magistrate, the collector, a commercial resident, and a salt agent (Qanungo, 2010). According to the Bengal Municipal Act of 1896, significant steps were undertaken for improving the aesthetic appearance of the surrounding urban area. New administrative structures, settlements, businesses, and trade centres were constructed with consideration of the beauty of the area's landscape, especially near waterways, which were also vitally associated with the town's drainage system via khal/canals and hilly streams. Historic evidence shows that the Chaktai Khal was not only a principal drainage channel, but also a major route for trade and commerce. From the $19^{\text {th }}$ century, the area around the Chaktai Khal continued to experience population growth and also saw the building of several warehouses or 'godowns' called 'gums' and 'golas'. Trading practices by different merchant groups impacted various settlement forms, and a significant feature was how the main buildings faced the waterfront (Qanungo, 2010). 
eTropic 19.2 (2020) Special Issue: Sustainable Tropical Urbanism

The shore of the Karnaphuli River, from the oldest waterfront area of Sadarghat to Patenga sea-beach on the bay, was once noted for walking and driving. However, after the First World War, the rate of urbanisation and modernisation of Chittagong town was rapid. By the early 1940s, Chittagong had become the third largest urban area in the province and its bustling environment was a source of pride (Qanungo, 2010). Today, the city of Chittagong is the second largest urban region and known as the trade capital of Bangladesh. It still retains worthy water landscape resources; however, in terms of urban waterfront development and management, very alarming consequences of adverse effects on the surrounding waterfront urban built environment have been observed over the last decade (Akter et al., 2017; Al Mamun, 2018; Al Mamun et al., 2019). In 1994, the important Chaktai Khal was 60 metres wide (CDA, 2008), whereas its current width is documented to be only 12 metres. This, in turn, affects natural water flow and environment, and impacts trade (Al Mamun, 2018).

Many old structures in Chittagong city that were built during the British Colonial period, as well as the earlier Mughal and Sultani eras, are now on the point of disintegration due to insufficient conservation and preservation management by the respective stakeholders, including: the Chittagong Development Authority, the Department of Archaeology, and the Ministry of Cultural Affairs (Qanungo, 2010; Uddin \& Roy, 2016). Of concern is that the government of Bangladesh has listed only five historic buildings in Chittagong as heritage sites (Uddin \& Roy, 2016). In 1995, a list of 34 old structures were suggested for protection and conservation as antiquities (the Antiquities Act of 1968/1976, refers to a cultural product over 100 years old), and these were presented in the Detailed Area Plan (DAP) of the Chittagong Metropolitan Area (CMA) as created by the Chittagong Development Authority (CDA) (DAP, 2009; Uddin \& Roy, 2016). However, no such initiatives are observed during the implementation stage of DAP (Chakraborty, 2010; Uddin \& Roy, 2016). This is despite the Structure Plan and Urban Development Master Plan of the Chittagong Metropolitan Area (CMA) already possessing a policy (code no PRS: 02) to preserve historical interest, for instance, in the form of buildings and monuments representing cultural and architectural essence (CDA, 2008; DAP, 2009). Furthermore, there is no evidence of context-based heritage identification and land use planning based analyses undertaken by historians or cultural investigators to identify the cultural image of the city of Chittagong (Chakraborty, 2010). 
eTropic 19.2 (2020) Special Issue: Sustainable Tropical Urbanism

Figure 1. The Trading Route as Symbol of Prosperity - Chaktai Khal

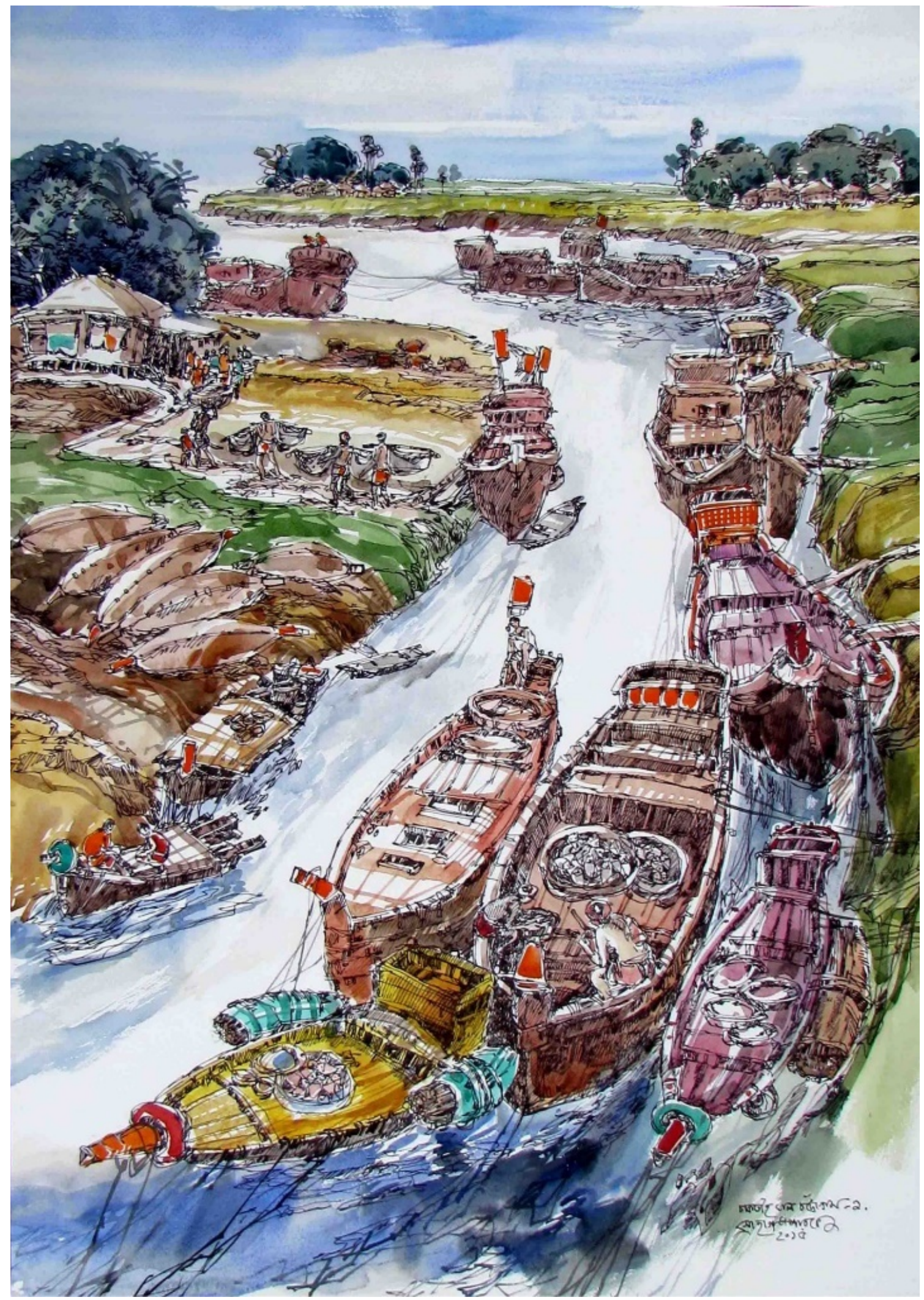

Source: Shohag Parvez, Artist (Parvez, n.d.)

eTropic: electronic journal of studies in the tropics 
eTropic 19.2 (2020) Special Issue: Sustainable Tropical Urbanism

Figure 2. The Trading Zone Settlement as Symbol of Prosperity - Chaktai Khal

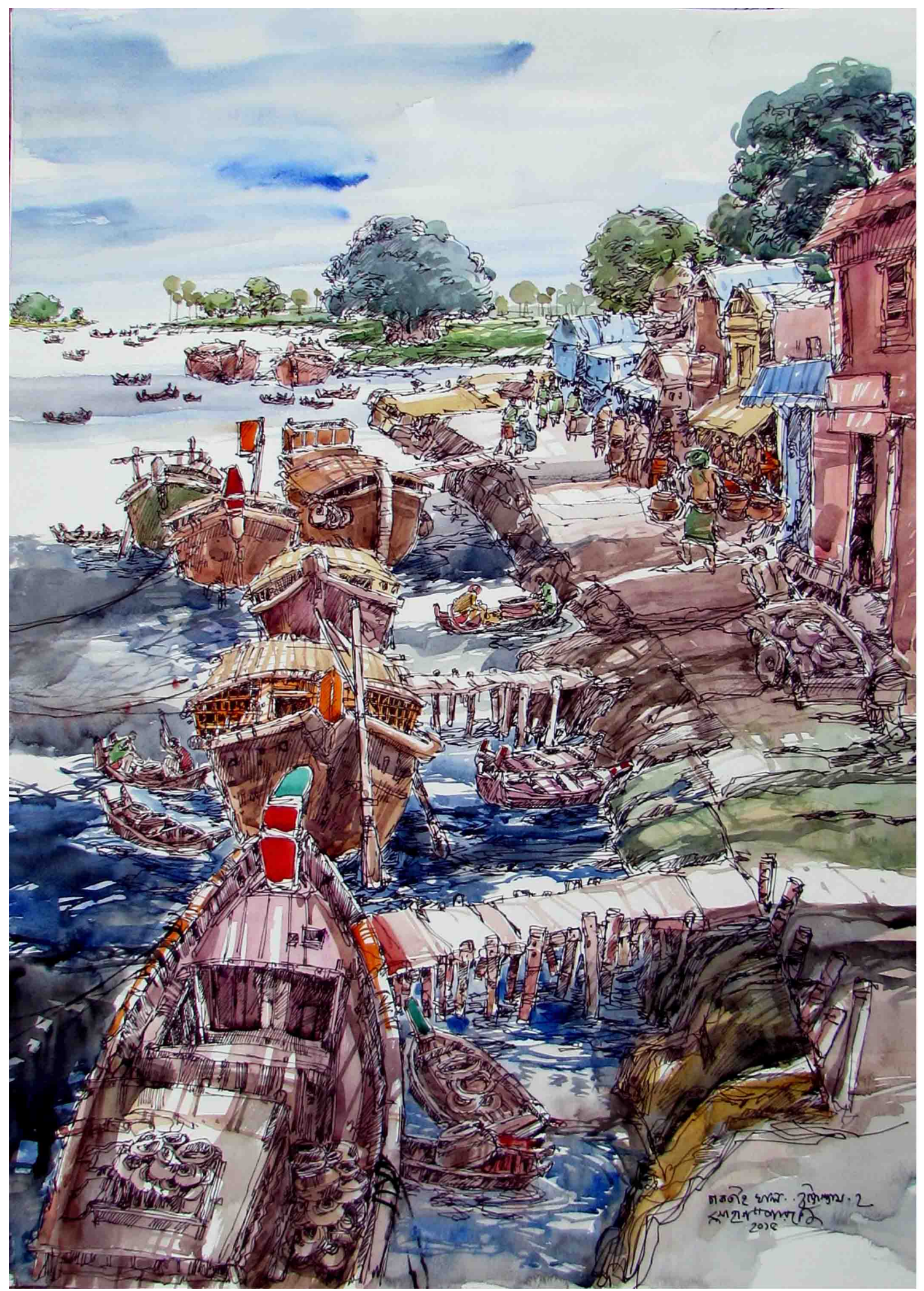

Source: Shohag Parvez, Artist (Parves, n.d.) 
eTropic 19.2 (2020) Special Issue: Sustainable Tropical Urbanism

\section{Literature Review}

Waterways are not only important for urban geographical environments but because they influence and confine their surrounding urban morphology they also perform a vital role in the shaping of societies and their economic growth (Abshirini \& Koch, 2016; Xie \& Gu, 2015). Urban morphology can be considered an important approach to urban design and studies in the creation of urban form. Such studies consider both the physical and spatial components of urban structure and urban landscape while incorporating the lessons of urban history (Lynch, 1960; Sanders, 2008; Whitehand, 2007). An early example of urban morphology by the geographer Hugo Hassinger in 1916 thoroughly mapped the historical architectural styles in the city of Vienna. Another example culminated in comprehensive classifications of the sites, ground plans, and building types of German towns by Walter Geisler in 1918 (Whitehand, 2007). In 1966, an important study by Conzen discussed how urban historical structures can be conserved through the application of urban morphology (Gu, 2014; Whitehand, 2007). He also stated that the ground plan, the building fabric, and land and building utilisation are the three morphological elements of an urban landscape that are derived from cultural contexts and historical processes (Gu, 2014). Landscape architect James Corner and his office envisioned a new Water City for 1.5 million inhabitants by recognising the importance of the landscape resource of water and using it to create a new city (del Pozo, 2013). Indeed, the heritage significance of water landscapes is receiving increasing recognition. The Chinese state governments have gazetted waterfront 'Clan Jetties' as a heritage village for connecting historical essence and value (Salim \& Mohamed, 2018). Old waterfront structures and heritage buildings are conserved for preservation or adaptive reuse by some cities with a view to economic benefits for the community (Clapp et al., 1997; Shamsuddin et al., 2012). In Malaysia, two historic trade centres on the Straits of Malacca, the cities of George Town and Melaka, have undergone rejuvenation successfully implemented through heritage waterfront redevelopment (Shamsuddin et al., 2012). Some researchers have highlighted that historic waterfront rejuvenation has played a significant role not only in creating new urban public spaces but also in improving the quality of the living urban environment (Rahman \& Imon, 2017; Shamsuddin et al., 2012; Yassin et al., 2010). Additionally, of importance, is that the preservation of all water forms are simultaneously a resource in urban planning (Ashley et al., 2013). In this regard, environmental issues and urban sustainability have been addressed with new methodologies to improve, reorganise and recover the existing waterfront by implementing many 'water sensitive design approaches' in developed countries (JSCWSC, 2009; Lerer et al., 2015). Moreover, these approaches to design are also culturally sensitive and characterise and amplify the locals' sense of belonging, ensuring a further sustainable approach for redevelopment (Rahman \& Imon, 2017; Shamsuddin et al., 2012). 
eTropic 19.2 (2020) Special Issue: Sustainable Tropical Urbanism

\section{Research Methodology and Study Area}

\section{Methods and Materials}

To date there is no theoretical assessment model used for analysing morphological patterns of heritage buildings in Bangladesh, especially within waterfront heritage areas. Therefore, a mixed-method approach has been utilised by incorporating primary and secondary data in order to produce a concrete outcome for the research. This paper unpacks and illustrates the historical existence of settlements along wateredges by examining historic evidence and old newspaper articles, as well as pinpointing selected structures through mapping satellite images and GIS data collected from the planning division of the Chittagong Development Authority (CDA). Additionally, in order to establish the morphological relationship between architectural characteristics of heritage structures and the urban waterfront of Chittagong city, the Conzen approach (Gu, 2014) has been applied in order to examine: (1) the ground plan, (2) the building fabric, and (3) land and building utilisation. The Conzen approach is an urban morphological coding-based analytical tool that can be applied to the conservation of urban history (Zeayter \& Mansour, 2018). Alongside this approach, a selection of scientific articles explicitly examining the role of waterfront functional clarity have been reviewed and analysed in order to ascertain the important connectivity between buildings and water.

Direct field observation has been conducted to ascertain the present condition of Chittagong waterfront, including identifying the change in functional use, building orientation, and physical accessibility. Direct observation has been substantiated by photographic data. Further field observation is supported by semi-structured interviews (fifteen respondents) with representatives of the local authorities (Chittagong Development Authority, and Chittagong City Corporation) and adjacent land users. An operation framework presents a diagrammatic overview of the steps involved in the research tasks and their outcomes. See Figure 3 below. 
eTropic 19.2 (2020) Special Issue: Sustainable Tropical Urbanism

Figure 3 Operational Framework

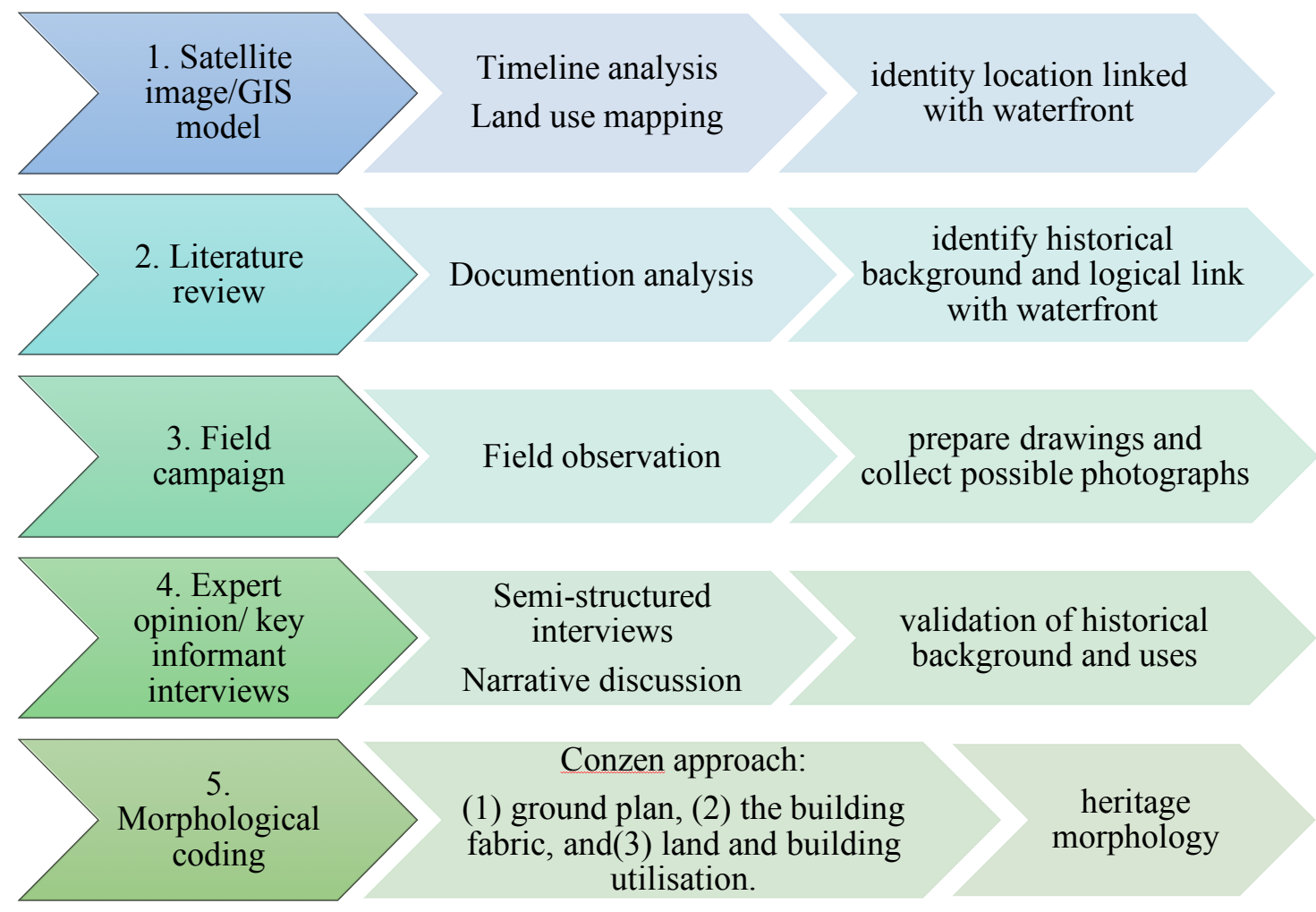

Source: Authors, (2020)

\section{Study Area}

Four historical buildings, marked under the categories of Type A, Type B, and Type $\mathrm{C}$, were selected for illustrating the research outcomes. Each of the buildings is almost 100 years old and all are situated along important waterways (Figures 4 and 5). Building Type $A$ is located along the Karnaphuli River but recent developments of surrounding buildings have curbed its connectivity with the waterway. The two Type B buildings and the Type $C$ building are situated alongside the Chaktai Khal as the canal flows downstream into the Karnaphuli River. The two Type B buildings are similar not only in their architectural features but also in their placement to adjacent water landscape settings. 
eTropic 19.2 (2020) Special Issue: Sustainable Tropical Urbanism

Figure 4 Satellite View of Study Zone

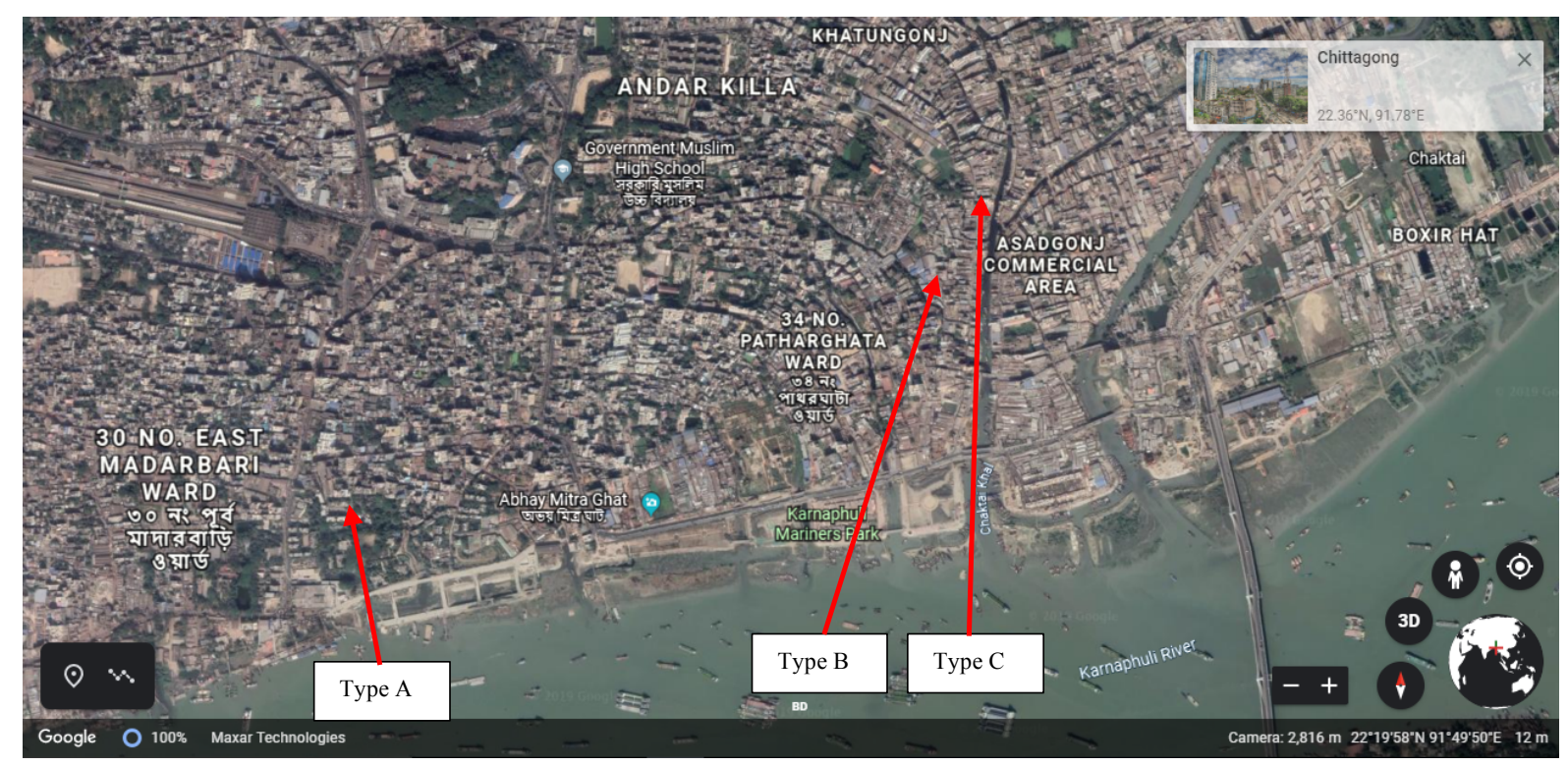

Source: Googleearth.com

Figure 5 GIS Map of Selected Historical Buildings

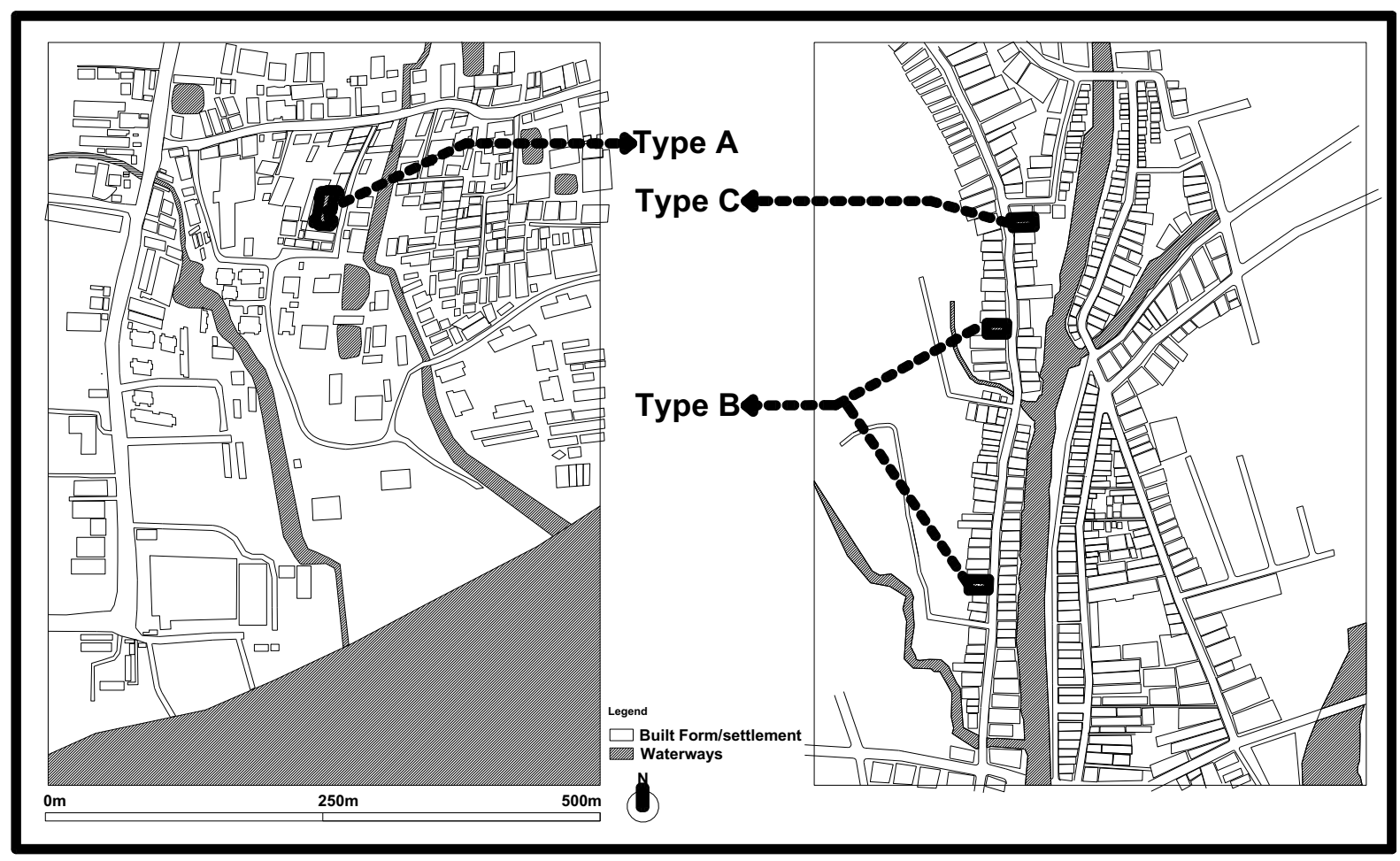

Source: Authors (2020). 
eTropic 19.2 (2020) Special Issue: Sustainable Tropical Urbanism

\section{Results and Discussion}

\section{Historical Coding}

Historically, the study zone was a well-known trading and business centre situated along major waterways as evidenced by its several heritage settlements. According to local knowledge, oral history, and secondary data, all historical buildings were constructed during the British colonial period (Table 1). Historical evidence suggests that building Type A was constructed in the early $19^{\text {th }}$ century during the late British colonial era (1920-1925 AD) and is known as 'PK Sen Bhaban', one of the traditional historic buildings in Chittagong. During the colonial period, it was one of the largest and tallest buildings in Chittagong Town (Chakraborty, 2010), and is situated in the old area of Sadarghat alongside the bank of the Karnaphuli River. The original owner Zemindar Prasanna Kumar Sen initiated its construction in 1920 and the building was completed in 1923 using concrete structural techniques and chun-surki (plaster and brick). This heritage building has six floors with forty large rooms. Today the rooms are used for residential purposes. The historical building is now surrounded by contemporary constructions (Razon, 2017).

Type $B$ and Type $C$ buildings are more than 80 years old and have no significant mention in the available literature or in reliable secondary sources. Nowadays, these buildings are used commercially as warehouses or 'godowns'. According to interviews with key informants, these buildings were constructed in the early $19^{\text {th }}$ century during the British colonial era. They were of historical importance and utility for both commercial and residential purposes. During the colonial period, trade relied on seasonal winds known as Maritime tropical air masses, and merchants staying in Chittagong for the duration of the months of the trading season (waiting for the winds to change), required long-term temporary residence. These buildings thus acted as warehouses on their lower floors and as dwellings, with rooms upstairs. The merchants preferred to rent the upper floor facing watercourses in order to enjoy the natural beauty of the town. 
eTropic 19.2 (2020) Special Issue: Sustainable Tropical Urbanism

Table 1 Waterfront View of Existing Buildings and their Timelines

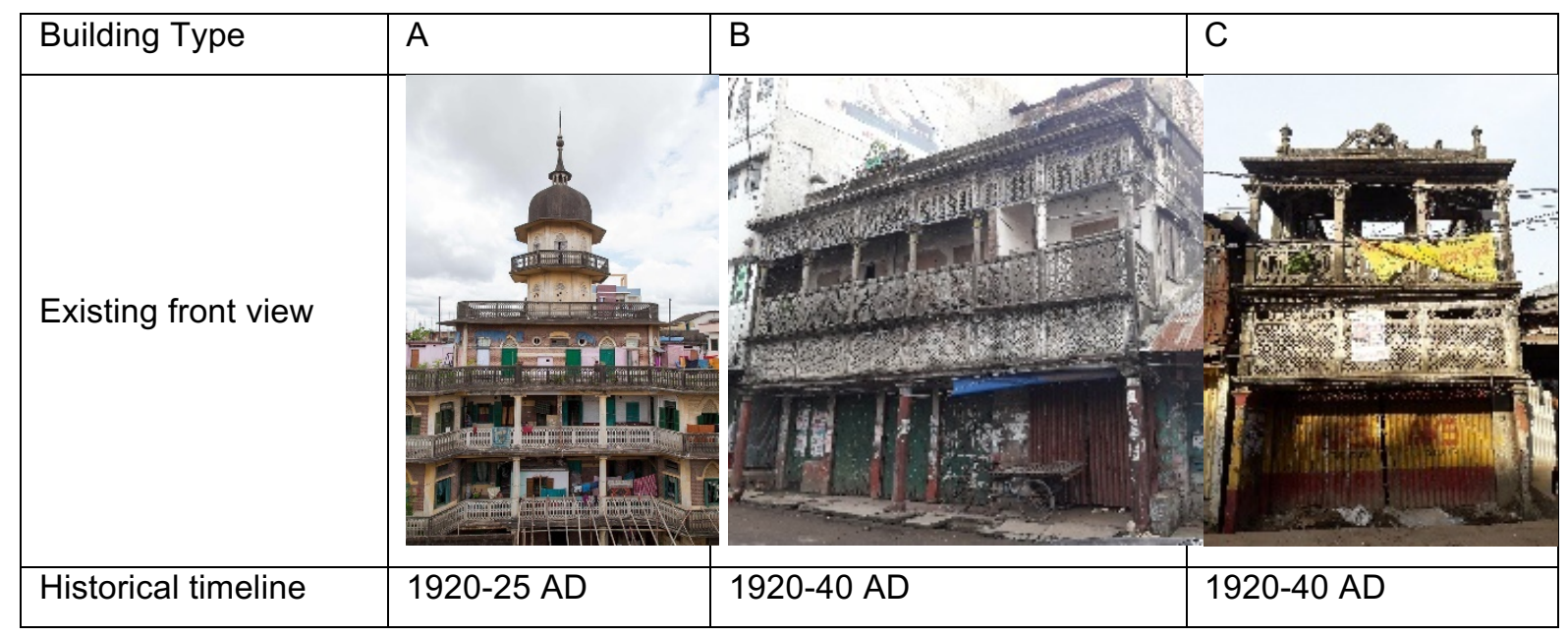

Source: Authors (2020).

Aiming to unpack the historical existence of water-edge heritage buildings from the perspective of historical coding, the study focuses on several key areas of conflict regarding the establishment of the buildings heritage significance. These include the interrelations between three aspects: information establishing the buildings' historic significance, and the conflicting contemporary situation of the buildings' compromised physical conditions, and their interrupted connectivity with the water-edge.

Firstly, these almost 100-year-old buildings, constructed in the early $19^{\text {th }}$ century of the British colonial era, not only present historical evidence of Chittagong city but also establish their setting along adjacent waterways. Despite the strong evidence of historic significance, no proactive initiatives to conserve and/or preserve them either locally or nationally have been identified. However, several articles and newspaper items have been published in order to create awareness for the preservation of the buildings. In 2010, an article was published in the Daily Star titled 'Preserve PK Sen Bhaban as Heritage' which made a case for documenting and preserving the building as a national heritage site (Chakraborty, 2010).

The second area of conflict is the declining physical conditions and the interrupted water-edge connectivity of the buildings. Due to the attraction and benefit of waterfront accessibility, there has been a throng of businesses locating to these areas and a surge in the construction of massive infrastructures, thus turning these sites into the densest area of the city. Consequently, the visual connectivity with the water-edge has been dramatically reduced, which leads to the eradication of local visual evidence regarding the buildings' historic water-based socio-economic integration and thus their 
heritage importance. Previously, water-based socio-economic integration which was intensely functional to the city and its users was evident, and was noted during field observations. However, the current development trends are forming additional boundaries hindering links with waterways, and rendering the heritage buildings overshadowed by surrounding infrastructures.

Thirdly, the Government of Bangladesh has amended three levels of the master plan for Chittagong city (the Structure Plan 1995/2015, Urban Development Master Plan 1995/2005, and the Detailed Area Plan 2009/2015), whereas no substantial proactive appraisals have been observed for protecting and/or conserving heritage structures. The absence of proper planning strategies for the preservation of the colonial structures located along waterways leads to further encroachment on these sites, resulting in illegal settlers constructing temporary and permanent markets, and the development of business centres and residential buildings. This results in a lack of visual evidence, and now no historically significant morphologies or distinct spaces are visible along the waterfront. The following artwork elevations show the current different development practices and different land-use activities (Figures 6 \& 7).

Figure 6 Street Level Elevation along the Waterfront (around Type C)

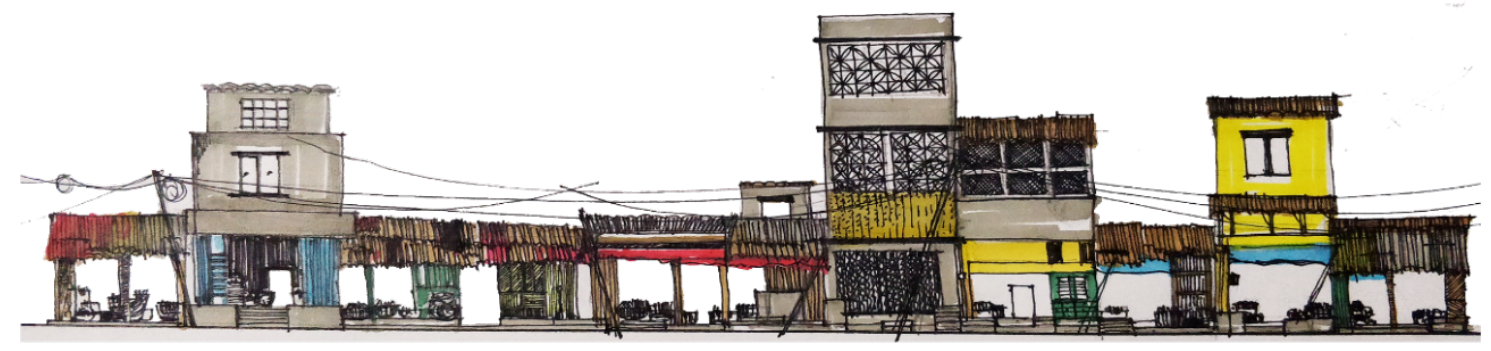

Source: Authors (2020).

Figure 7 Street Level Elevation along the Waterfront (around Type B)

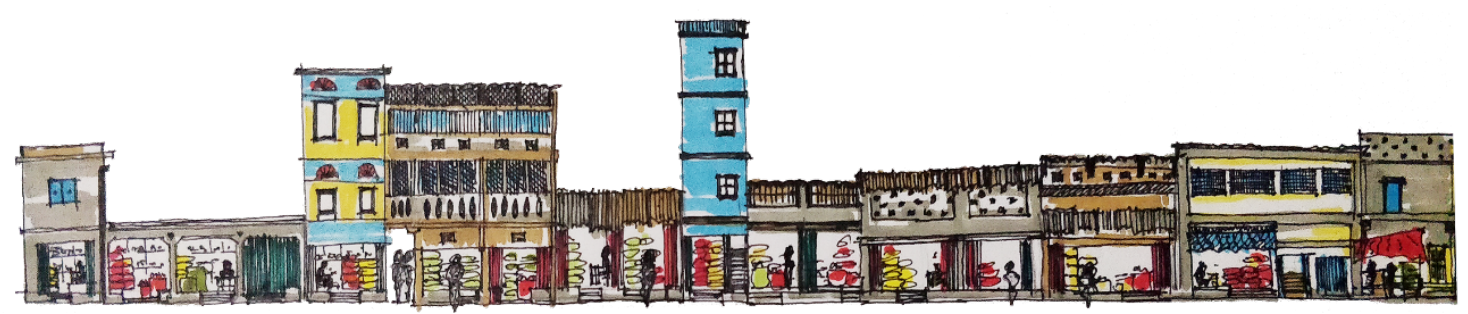

Source: Authors (2020). 
eTropic 19.2 (2020) Special Issue: Sustainable Tropical Urbanism

\section{Morphological Coding}

To further analyse the heritage significance of the selected case study buildings Type A, Type B, and Type C, it was necessary to undertake morphological coding using Conzen's approach. The coding results have shown three distinct pieces of evidence addressing the orientation, accessibility, and functions of the historical buildings that demonstrate how they are explicitly and sensitively connected with the water-edge.

First, according to Conzen's (Gu, 2010; Whitehand, 2007) morphological coding (Table 2) undertaken for the ground floor plan, each type of building under study has been oriented towards the waterfront. Building Type $C$ obtains water-edge connectivity with the back of the building, while the plans of the two buildings Type B illustrate connectivity at both the front and the back of the buildings. The ground level layout of building Type A shows it is elongated along a north-south direction, which not only orients it toward the water channel but also organises its peripheral functions (e.g., living room, dining room, and frontal accessible common corridor) by considering waterfront view rather than the local climatic benefit of wind flow. Furthermore, the waterside main entrance evidences how the approach of the building design prioritised the frontal circulation flow. The upper floors of the building were used for private purposes and the top floor was used as a lighthouse to navigate river ships. This building was one of the tallest structures of the British era and was prominent as a multifunctional building. Moreover, the formation of a concave layout and visual connectivity through indoor to outdoor spaces using large windows/openings offering views of the waterscape is a core feature of the building. Additionally, a sacred place for spiritual purposes was observed on the top floor facing the river. The front open space of this building was used as a playground. The Type $B$ and $C$ buildings also demonstrate similar functional arrangements as the Type A building - for instance, the ground level used for public purposes and the upper floor for accommodation, where a waterside verandah is to be found - and visual connectivity with the waterfront. In addition, the service areas of Types A and B buildings - for instance, the staircase and kitchen area - are located at the back, showing functional clarity regarding public and private spaces, but facing away from the water's-edge. The functional connectivity of building Type $C$ with the waterway, is practical; the service area is located near the water channel, taking advantage of water resources for water collection purposes and drainage facilities.

Secondly, the heritage value of the selected case study buildings can be ascertained through their decorative elements. Significant decorative items on the front facade and overall detailed ornamentations have been observed in building Type A, including: stone-carved jali screens, big ventilators with geometric shapes, fenced railing, Corinthian Greek columns, and less decorative screenings. 
eTropic 19.2 (2020) Special Issue: Sustainable Tropical Urbanism

Table 2 Morphological Coding through Conzen's Approach

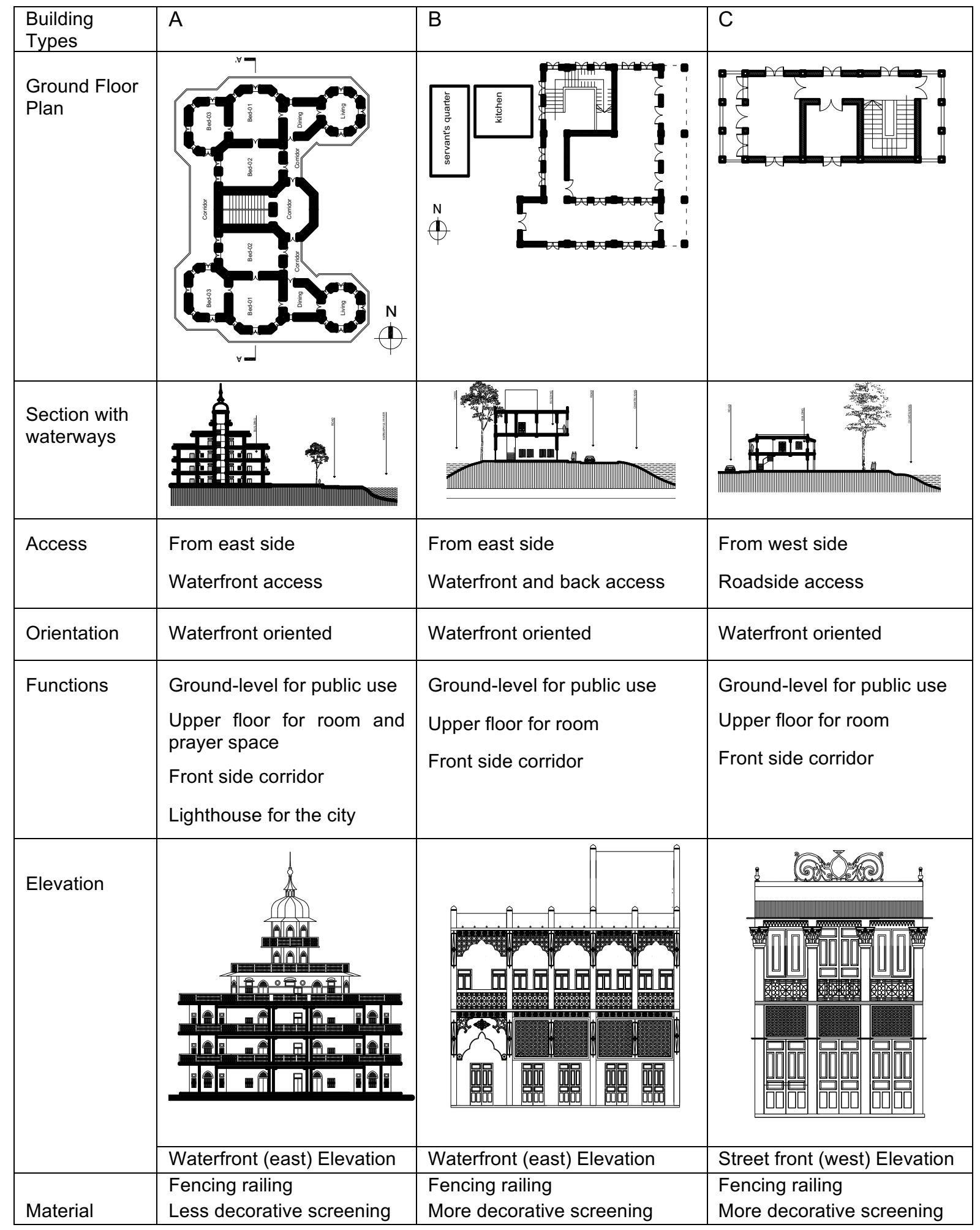

Source: Authors (2020) 
eTropic 19.2 (2020) Special Issue: Sustainable Tropical Urbanism

All the buildings were constructed by using concrete structural techniques and chunsurki (plaster and brick). While, cement plaster was used for climatic benefits and durability.

Thirdly, an analysis of the heritage significance of the selected case study buildings necessitates an examination of the site's land use - which reveals a mixed-use pattern. The ground level of Type A is noted for a fully residential practice where common facilities such as dining room, living room, kitchen, and guest room have public function. Ground levels of Types B and C were conceived for commercial uses such as godowns and wholesale storage because of the convenience of loading and unloading goods from waterside canal docks. However, in both types of building, the upper level is arranged for accommodation with the verandah placed along the waterside of the building in order to enjoy the beauty of the aquatic landscape. Currently, the functions of the two Type B buildings in this study are diverse, whereas building Type $C$ is used only for storage due to concerns regarding its structural stability.

This research has found that building orientation, physical accessibility, and visual connections through internal and external functions were not only explicitly organised with consideration to the water-edge but also sensitively associated with the intrinsic values of history. From the visual observation of architectural drawings, functional layouts, and interpretation of the building materials and decorative elements of the British era, it may be argued that morphological formation along with waterway interfaces emerged through building layouts, functional clarity, and land use classification.

\section{Conclusions}

This study examined the historical existence of Chittagong city within its landscape of historical structures near the prominent waterfront of Karnaphuli River and the Chaktai Khal canal through a process of historical coding and urban morphological coding. These structures had been functioning as a context for water-edge development and supporting urban water management of the city. The study has found that insensitive development along waterways and the deteriorating and impeded visual connectivity between the city's old buildings and the water-edge is the main obstacle in establishing these buildings' past existence and their historical essence which hinders establishing the buildings as of heritage significance and thus implementing their conservation and or preservation. Throughout architecture's chronological development, various building typologies have emerged and affected activities in public spaces. A sensitive revival process along the waterside can enrich local business and trade and also positively impact the overall cityscape. However, contemporary urban development 
eTropic 19.2 (2020) Special Issue: Sustainable Tropical Urbanism

pressures and lack of conservation and preservation measures on the part of the responsible authorities are affecting the physical features of old structures and the overall development of this significant heritage area. Hence, the urban design process needs to integrate waterfront historical evidence into a future urban master plan. With the instigation of sensitive heritage planning, the waterfront area of Chittagong city could be used as an example for sustainable urban water-edge design. To this end, policymakers need to review relevant policy analysis and more case studies need to be undertaken that address how to conserve and/or preserve water-edge historical evidence, such as heritage buildings and historical public spaces. Historians and cultural investigators may use this case study as a theoretical and methodological reference point for further identifying the urban fabric of Chittagong city. Future research may also cover broader aspects of water-based historical conservation and preservation policy analysis, which would contribute to a more inclusive practice with regards to the changes in water-landscape peripheries caused by urbanisation trends. 
eTropic 19.2 (2020) Special Issue: Sustainable Tropical Urbanism

\section{References}

Abshirini, E., \& Koch, D. (2016). Rivers as integration devices in cities. City, Territory and Architecture, 3(1), 1. https://doi.org/10.1186/s40410-016-0030-4

Al Mamun, M. M., (2018). Improve urban waterways management in Chattogram city - OpEd - observerbd.com. https://www.observerbd.com/details.php?id=149108

Al Mamun, M. M., \& Kim, S. M. (2020). Stakeholder analysis matrix for buffer zone management in the peri-urban area of Chittagong, Bangladesh. Environment, Development and Sustainability, 22(6), 5503-5520. https://doi.org/10.1007/s10668019-00435-z

Al Mamun, M. M., Begum, A. A., \& Paul, P. (2019). Welcoming Water for Changing Urban Morphology: A Biophilic Design Approach. ARCASIA Forum 20 Conference Dhaka "Architecture in a Changing Landscape," 107-117.

Akter, A., Mohit, S. A., \& Chowdhury, M. A. H. (2017). Predicting urban storm water-logging for Chittagong city in Bangladesh. International Journal of Sustainable Built Environment, 6(1), 238-249. https://doi.org/10.1016/.ijsbe.2017.01.005

Ashley, R., Lundy, L., Ward, S., Shaffer, P., Walker, L., Morgan, C., Saul, A., Wong, T., \& Moore, S. (2013). Water-sensitive urban design: opportunities for the UK. Municipal Engineer, 166(2), 65-76. https://doi.org/10.1680/muen.12.00046

CDA. (2008). Urban Development Master Plan (2nd ed., Issue 1). Chittagong Development Authority and Ministry of Housing and Public Works.

Chakraborty, P. (2010, November 4). Preserve PK Sen Bhaban as heritage. The Daily Star. https://www.thedailystar.net/news-detail-161170

Clapp, J. A., Weisbrod, R. E., Eichenbaum, J., Little, R., \& Eberhard, J. P. (1997). Book reviews. Journal of Urban Technology, 4(3), 97-107. https://doi.org/10.1080/10630739708724569

DAP. (2009). Detailed Area Plan for Chittagong Metropolitan City, Pub. L. No. Chittagong Development Authority Ordinance 1959 (E.P. Ord. No. LI of 1969), 210. https://cda.gov.bd/detailed-area-plan/

del Pozo, C. (2013). Landscape Oriented Urban Strategies. Strategies for the PostSpeculative City. J. Arana \& T. Fanchini (Eds). EUSS 2013. ISOCARP. http://www.sunlight.es/landscape-oriented-urban-design-strategies/

Daglioglu, E. K. (2015). The Context Debate: An Archaeology. Architectural Theory Review, 20(2), 266-279. https://doi.org/10.1080/13264826.2016.1170058

Gu, K. (2010). Urban morphological regions and urban landscape management: The case of central Auckland, New Zealand. URBAN DESIGN International, 15(3), 148-164. https://doi.org/10.1057/udi.2010.4

Gu, K. (2013). Waterfront Regeneration: Experiences in City-building. Urban Policy and Research, 31(3), 386-388. https://doi.org/10.1080/08111146.2013.807006

Gu, K. (2014). From urban landscape units to morphological coding: Exploring an alternative approach to zoning in Auckland, New Zealand. URBAN DESIGN International, 19(2), 159-174. https://doi.org/10.1057/udi.2013.21

Gültekin, Ç. (2012). Rethinking the Role of Context and Contextualism in Architecture and Design (Issue September) [Eastern Mediterranean University]. http://irep.emu.edu.tr:8080/xmlui/bitstream/handle/11129/348/Cizgen.pdf?sequence=1

Harding, S., Bird, G., Losos, E., Aderolili, R., \& Hotez, P. (2016). International Day of the Tropics: Towards a better global future. eTropic: electronic journal of studies in the tropics 15 (2), 5-12. https://doi.org/10.25120/etropic.15.2.2016.3538 
Hussain, A., Yazid, M., Yunos, M., Ismail, S., Utaberta, N., Ismail, N. A., Arifin, N. F., Rahayu, I., \& Daud, L. (2015). The Role of Urban form at Historical Waterfront: Case of Marsaxlokk Waterfront. Advances in Environment Biology, 9(24), 142-146.

JSCWSC. (2009). Evaluating Options for Water Sensitive Urban Design - A National Guide. https://doi.org/10.1017/CBO9781107415324.004

Lerer, S., Arnbjerg-Nielsen, K., \& Mikkelsen, P. (2015). A Mapping of Tools for Informing Water Sensitive Urban Design Planning Decisions-Questions, Aspects and Context Sensitivity. Water, 7(3), 993-1012. https://doi.org/10.3390/w7030993

Liu, L., \& Jensen, M. B. (2018). Green infrastructure for sustainable urban water management: Practices of five forerunner cities. Cities, 74(October), 126-133. https://doi.org/10.1016/j.cities.2017.11.013

Liverpool City Council. (2020). Home | Liverpool World Heritage. https://www.liverpoolworldheritage.com/

Lynch, K. (1960). The Image of the City. In The Joint Center for Urban Studies, a cooperative venture of the Massachusetts Institute of Technology and Harvard University. The M.I.T. Press. https://doi.org/10.2307/427643

Ocón, D. (2018). The heritage-making conundrum in Asian cities: Real, transformed and imagined legacies. eTropic: electronic journal of studies in the tropics 17 (1), 90-116. https://journals.jcu.edu.au/etropic/article/view/3644

Parvez, S. (n.d.). Shohag Parvez Art Work - Art People Gallery. Retrieved November 20, 2020, from https://www.artpeoplegallery.com/shohag-parvez-art-work/

Qanungo, S. B. (2010). A History of Chittagong Vol. II (1761-1947) (D. Qnungo (Ed.); 1st ed.). Shanti Press.

Rahman, M. M., \& Imon, S. S. (2017). Conservation of Historic Waterfront to Improve the Quality of Life in Old Dhaka. International Journal of Architectural Research: ArchNet-IJAR, 11(2), 83. https://doi.org/10.26687/archnet-ijar.v11i2.1170

Rashid, M. A. U. H., Manzoor, M. M., \& Mukhtar, S. (2018). Urbanization and its effects on water resources: An exploratory analysis. Asian Journal of Water, Environment and Pollution, 15(1), 67-74. https://doi.org/10.3233/AJW-180007

Razon, A. A. (2017). A Study of Space Use Pattern and Historical Residential Building Morphology of Chittagong. International Journal of Scientific \& Engineering Research, 8(2), 618-627. https://doi.org/10.14299/ijser.2017.02.006

Salim, N., \& Mohamed, B. (2018). The evolution of historic waterfront: A case study of George Town, Penang. Planning Malaysia, 16(4), 40-54. https://doi.org/10.21837/pmjournal.v16.i8.537

Samsudin, N., \& Jaffar, A. (2017). Kuala Terengganu "Waterfront Heritage City"-"Heritage" Disrespecting Heritage. http://www.academia.edu/35447285/Kuala Terengganu Waterfront Heritage City Heritage Disrespecting Heritage

Sanders, P. S. (2008). Presenting the Past: The Impact of Urban Morphology in Shaping the Form of the City. ACSP-AESOP 4th Joint Congress, Bridging the Divide: Celebrating the City. http://eprints.qut.edu.au/17804/1/c17804.pdf

Schuch, G., Serrao-Neumann, S., Morgan, E., \& Low Choy, D. (2017). Water in the city: Green open spaces, land use planning and flood management - An Australian case study. Land Use Policy, 63, 539-550. https://doi.org/10.1016/j.landusepol.2017.01.042

Shamsuddin, S., Sulaiman, A. B., Latip, N. S. A., Amat, R. C., \& Alias, N. A. (2011). Sustainable historic waterfront development: Approaches and dilemma of two 
eTropic 19.2 (2020) Special Issue: Sustainable Tropical Urbanism

UNESCO world heritage sites in Malaysia. WIT Transactions on Ecology and the Environment, 155(May), 745-756. https://doi.org/10.2495/SC120632

Silva, J. B., Serdoura, F., \& Pinto, P. (2006). Urban Rivers as Factors of Urban (Dis)integration. 42nd ISOCARP Congress, 14-18.

Smith, H., \& Ferrari, M. S. G. (2012). Waterfront Regeneration Experiences in City-building (H. Smith \& M. S. G. Ferrari (Eds.); 1st ed., Issue 1). Routledge. https://doi.org/10.4324/9780203133378

Uddin, M., \& Roy, P. (2016). Ctg historic sites left in ruins. The Daily Star. https://www.thedailystar.net/backpage/ctg-historic-sites-left-ruins-1199806

Whitehand, J. W. R. (2007). Conzenian urban morphology and urban landscapes. 6 th International Space Syntax Symposium, ii-1-ii-9. http://www.spacesyntaxistanbul.itu.edu.tr/papers/invitedpapers/Jeremy whitehand.p df

Wong, T. (2006). Water sensitive urban design - the journey thus far. Australasian Journal of Water Resources, 10(3), 213-222. https://doi.org/10.1080/13241583.2006.11465296

Xie, P. F., \& Gu, K. (2015). The changing urban morphology: Waterfront redevelopment and event tourism in New Zealand. Tourism Management Perspectives, 15, 105114. https://doi.org/10.1016/j.tmp.2015.05.001

Yang, N., \& Soraya, M. (2013). Water by Design: A Shifting Paradigm in Urban Built Environment. Proceedings of the SB 13 Singapore- Realising Sustainability in the Tropics, 7, 978-981.

Yassin, A. B., Eves, C., \& Mcdonagh, J. (2010). An evolution of waterfront development in Malaysia. 16th Pacific Rim Real Estate Society Conference, January, 1-14. http://researcharchive.lincoln.ac.nz/handle/10182/3215

Zeayter, H., \& Mansour, A. M. H. (2018). Heritage conservation ideologies analysis Historic urban Landscape approach for a Mediterranean historic city case study. HBRC Journal, 14(3), 345-356. https://doi.org/10.1016/j.hbrcj.2017.06.001 
eTropic 19.2 (2020) Special Issue: Sustainable Tropical Urbanism

\section{Acknowledgements}

The authors thank James Cook University Singapore for accepting our research for presentation at the "1st Sustainable Tropical Urbanism Symposium: Tropical Cities in a Warming World', 27 September 2019. We are also grateful for the valuable comments and directions to improve this paper offered by the conference conveners and eTropic editors, and to Shohag Parvez for permission to use his artworks. This research did not receive any specific grant from funding agencies in the public, commercial, or not-for-profit sectors.

Md Mustiafiz Al Mamun has been working as an Assistant Professor in the Department of Architecture, the Faculty of Architecture and Planning, Chittagong University of Engineering \& Technology (CUET), Chattogram, Bangladesh. Al Mamun completed his Bachelor degree in Architecture at Khulna University (KU), Khulna, Bangladesh, and Master of Science in Urban Environmental Management at the Asian Institute of Technology (AIT), Thailand. His research areas are Urban and Peri-Urban Morphology, Urban Landscape (blue and green), Urban Environment and Management, and Sustainable Tourism. He is a full member of the Institute of Architects Bangladesh (IAB), and International Society of City and Regional Planners (ISOCARP). He is a Member Secretary - (Education) of the IAB Chattogram Chapter (2019-2020). Mustiafiz Al Mamun is the founder and coordinator of Urban Talk (UT), Bangladesh, a research-based networking platform for young researchers and professionals.

Pranjib Paul has a Bachelor degree in Architecture from Chittagong University of Engineering and Technology (CUET) and is now working as a Junior Architect at Doshomik Sthapathi, Chittagong. He started his career as a Research Assistant in the Department of Architecture, CUET and has expertise in building information modelling, building environmental simulation and life cycle analysis tools. His research interests include Urban Environment, Urban Morphology, Building Envelope and Thermal performance on which he has published several international conference papers.

Sadman Noor graduated with a Bachelor degree in Architecture from Chittagong University of Engineering and Technology (CUET) and is now working as a Junior Architect at an architectural consultancy firm. His research interests are urban heritage conservation and urban design.

Anjuman Ara Begum is a Principal Architect at Doshomik Sthapathi, Chattogram. Anjuman Ara completed her Bachelor degree in Architecture at Khulna University $(\mathrm{KU})$, Khulna, Bangladesh. Her research areas are Architecture, Society and Urban studies. She is a Full member of the Institute of Architects Bangladesh (IAB), and currently a Member-Culture of the IAB Chittagong Chapter, Bangladesh (2017-2020). 